\title{
ロータ・磁気軸受系の同時最適設計*
}

$$
\text { 岩壸 卓 三*1, 中島 篤*2 }
$$

\section{Simultaneous Optimum Design of Rotor/Magnetic Bearing System}

\author{
Takuzo IWATSUBO ${ }^{* 3}$ and Atsushi NAKASHIMA \\ ${ }^{* 3}$ Department of Mechanical Engineering, The Faculty of Engineering, Kansai University, \\ 3-3-35 Yamate, Suita-shi, Osaka, 564-8680 Japan
}

\begin{abstract}
In this study, a new simultaneous optimization method to design a rotor supported by an electromagnetic bearing is proposed. In this method a cross-section area of the magnet and number of coil turns, an electromagnet configuration, control gains under the capacity of amplifier and magnetic flux saturation are simultaneously designed under constraints of the maximum bearing outside diameter and bias gap. The result is checked by post design analysis and the validity was shown by using an example.
\end{abstract}

Key Words: Simultaneous Optimum Design, Magnetic Bearing, Rotor Magnetic Bearing System, Electric Magnetic Design

\section{1. 緒}

磁気軸受を用いた回転機械は一般産業用に実用化 され，その用途も拡大している(0). しかし磁気軸受 を設計する際には, 経験を頼りに試行錯誤を重ねてい るのが現状である. そこで, 磁気軸受の設計経験がな くても, 簡単に最適な設計が行えるようなシステムが できることが望ましい，ところが現状では，まず機械 構造物の設計を行い，その構造物に適した制御系を設 計するという手順て設計されている(このような設計 法を本論文では “構造系と制御系の別々設計” (呼 ぶ) .そのため, 制御しやすい構造物というような制 御系設計の立場からの設計情報が構造設計に反映され ていない：この問題を解決するために，構造系と制御 系の相互関保を考慮して両者を同時に最適化する “構 造系之制御系の同時最適設計”(付なわち制御系の 設計の際に構造系が確定している別々設計と違って, 同時最適設計では制御系の情報を含む評価関数に基づ いて構造系を変更することができることから，制御し やすい構造を設計することができる可能性がある.

そこで, 本研究では設計者が設計仕様を入力する とロータと磁石の形状, コイル巻数などと制御を含む

* 原稿受付 2005 年 6 月 13 日

*1 正員, 関西大学工学部 (画564-8680 吹田市山手町 3-3-35).

*2 (株) 富士重工業(㤲373-8555 太田市スバル町 1-1) [元：神 戸大学大学院]

E-mail : iwatsubo@ipcku.kansai-u.ac.jp
磁气軸受系の最適設計を同時に行う設計法を提案する. まず磁気軸受を用いたロータ・軸受系の基礎モデルを 構築し, そのモデルにおける設計項目を設計変数とし て, 別々設計法により初期設計を行う. その初期設計 結果を設計変数の初期值とし, 同時最適化問題を解く.

\section{2. 設計対象のモデル化}

本章では，設計対象となるロー夕磁気軸受系の基礎 モデルを構築する.

2.1 ロータ制御系のモデル化 本研究では, ロータ磁気軸受特性を考慮したモデルを考える，構 造系は有限要素モデルを用い, 制御系はモード解析 法によって低次元化された構造系に対して設計する ものとする.

質量マトリクス $M$, 減衰マトリクス $G$ 剛性マト リクス $K$ を有する有限要素モデルに対して, 制御力 と外力が作用する閉ループ系の運動方程式は,

$$
M \ddot{q}+C \dot{q}+K \boldsymbol{q}=L_{a} u+L_{d} f
$$

ただし, $\boldsymbol{q}$ は弾性ロータ有限要素モデルの節点ベク トルを示し, 並進変位と回転変位の自由度を有する. $\boldsymbol{u}$ は磁気輯受の吸引力に関するベクトルを示し，L口は 磁気軸受の配置を示す行列を示す. $\boldsymbol{f}$ は外力ベクトル で弾性ロー夕に作用する不つりあい力やその他の外力 
を示し， $L_{\boldsymbol{d}}$ は外力が作用する位置を表す行列である. 式(1)の右辺第 1 項の動的吸引力 $u$ は,

$$
\boldsymbol{u}=k_{i} \boldsymbol{i}+k_{x} \boldsymbol{L}_{s} \boldsymbol{q}
$$

ただし，

$$
\begin{aligned}
& k_{i}=2 k \frac{I_{\text {bias1 } 1}-I_{\text {bias } 2}}{\left(X+X_{0}\right)^{2}}, k_{x}=2 k \frac{I_{\text {bias } 1}{ }^{2}-I_{\text {bias } 2}{ }^{2}}{\left(X+X_{0}\right)^{3}} \cdots(3) \\
& k=\frac{N^{2} \mu_{0} S}{4}
\end{aligned}
$$

とする. ここで，Lははセンサーの位置を表す行列であ り，X, I $I_{b \times l}, I_{b \times 2}$ は定常ギャップと電磁石 1,2 の定常 電流を示し, $\boldsymbol{k}_{\boldsymbol{x}}$ は電磁石の負ばね定数, $\boldsymbol{k}_{i}$ は電流午イ ン, $\boldsymbol{i}$ は電磁石の制御電流， $N$ は電磁石のコイル巻き 数, $\mu_{0}$ は真空透磁率, $S$ は電磁石鉄心の対向面積, である.

この微分方程式をモード解析法によりモード座標 系の表示 $\eta$ に変換すると,

$$
\widetilde{\boldsymbol{M}} \ddot{\boldsymbol{\eta}}+\widetilde{\boldsymbol{C}}_{n} \dot{\boldsymbol{\eta}}+\widetilde{\boldsymbol{K}}_{n} \boldsymbol{\eta}=\boldsymbol{\Phi}^{T} \boldsymbol{L}_{d} \boldsymbol{f}
$$

ここでФは座標変換ベクトルである.ささら，式 (4)を制御するモードまでに低次元化すると次式のよう に表される.

$$
\tilde{\boldsymbol{M}}_{r} \ddot{\boldsymbol{\eta}}_{r}+\widetilde{\boldsymbol{C}}_{n r} \dot{\boldsymbol{\eta}}_{r}+\widetilde{\boldsymbol{K}}_{n r} \boldsymbol{\eta}_{r}=\boldsymbol{\Phi}_{r}^{T} \boldsymbol{L}_{d} \boldsymbol{f} \cdots(5)
$$

ただし，クrはクの制御しようとするモードまでの ベクトルである.

2.2 電磁石設計法電磁石を設計寸る際には, アンプの容量や磁束飽和などを考慮した上で, 電磁 石用鉄心の形状・断面積やコイル巻き数などを決定 する必要があり，その電磁石を磁気軸受に適用する となると電磁石と磁気軸受に関する知識と経験が必 要となる.ここでは電磁石の設計方法を述べる.(

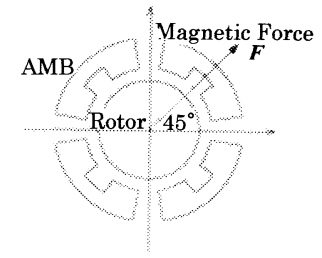

Fig.1 Configuration of electromagnet
図1のように向かいあった二つの電磁石を垂直 方向から $45^{\circ}$ ずらして二組配置する場合について 考える. 電磁石の吸引力は次式のように表される.

$$
F=\frac{N^{2} \mu_{0} S}{4}\left(\frac{i_{1}}{\frac{l}{2 \mu_{s}}+x_{1}}\right)^{2}-\frac{N^{2} \mu_{0} S}{4}\left(\frac{i_{2}}{\frac{l}{2 \mu_{s}}+x_{2}}\right)^{2} \cdots \cdots(6)
$$

ここで， $i_{1}, i_{2}$ は上下の電磁石 1,2 のコイル電流, $l$ は磁路長さ， $\mu_{5}$ は電磁石鉄心の比透磁率， $x_{1}, x_{2}$ 上下 の電磁石 1,2 とロータのギャップを示す.

磁気軸受の吸引力の制御に線形制御理論を適用寸 るために, 磁気軸受部の平衡点まわりでのロータの曲 げ振動による並進変位を考えて式(6)を線形近似する. そのためにここでは,

$$
\begin{aligned}
& x_{1}=X+x^{\prime}, i_{1}=I_{\text {bias } 1}+i^{\prime} \\
& x_{2}=X-x^{\prime}, i_{2}=I_{\text {bias } 2}-i^{\prime}
\end{aligned}
$$

とおく. $x$ ’,$i$ はそれぞれギャップとコイル電流の 変動成分を示す. 式(6)は,

$$
F=k \frac{I_{\text {bias }}{ }^{2}-I_{\text {bias }}{ }^{2}}{\left(X+X_{0}\right)^{2}}+2 k \frac{I_{\text {bias }}-I_{\text {bias } 2}{ }^{\prime}-2 k}{\left(X+X_{0}\right)^{2}}-2 k \frac{I_{\text {bias }}{ }^{2}-I_{\text {bias }}{ }^{2}}{\left(X+X_{0}\right)^{3}} x^{\prime}
$$

上式第 1 項はロータの自重とつりあう静的吸引力 $F_{\text {sadi }}$ を, 第 $2 \cdot 3$ 項は動的吸引力 $F_{\text {dmanix }}$ を表す.

$$
\begin{aligned}
& F_{\text {static }}=k\left(\frac{I_{\text {bias } 1}}{X_{0}+X}\right)^{2}-k\left(\frac{I_{\text {bias } 2}}{X_{0}+X}\right)^{2}=k \frac{I_{\text {bias1 }}{ }^{2}-I_{\text {bias } 2}^{2}}{\left(X+X_{0}\right)^{2}} \cdot(9) \\
& F_{\text {dynamic }}=2 k \frac{I_{\text {bias } 1}-I_{\text {bias } 2}}{\left(X+X_{0}\right)^{2}} i^{\prime}-2 k \frac{I_{\text {bias } 1}{ }^{2}-I_{\text {bias } 2}{ }^{2}}{\left(X+X_{0}\right)^{3}} x^{\prime} \cdot(10)
\end{aligned}
$$

式(10)より，線形近似された磁気軸受の動的吸引力は, コイル電流の変化分 $i^{\prime}$ とロータの変位 $x^{\prime}$ にそれぞれ 比例することが分かる.

ここで, 電磁石に求められる事は静的な吸引力を発生 させるために必要なバイアス電流による消費電力が小 さいことと, わずかな制御電流で振動制御を行えるこ との二つである.

まず, バイアス電流による消費電力を考える.こ こで, 静的吸引力とロータ質量の自重とのつりあいよ りロータを浮上させるために必要なバイアス電流はそ れぞれ次式で表される. 


$$
\begin{gathered}
I_{\text {bias } 1}=\left(X+X_{0}\right) \sqrt{\frac{4 \gamma M g}{\sqrt{2} \mu_{0}}} \cdot \frac{1}{\sqrt{N^{2} S}}=\frac{k_{\text {bias } 1}}{\sqrt{N^{2} S}} \\
I_{\text {bias } 2}=\left(X+X_{0}\right) \sqrt{\frac{4(\gamma-1) M g}{\sqrt{2} \mu_{0}}} \cdot \frac{1}{\sqrt{N^{2} S}}=\frac{k_{\text {bias } 2}}{\sqrt{N^{2} S}} \\
\left(\begin{array}{l}
k_{\text {bias } 1}=\left(X+X_{0}\right) \sqrt{\frac{4 \gamma M g}{\sqrt{2} \mu_{0}}} \\
k_{\text {bias } 2}=\left(X+X_{0}\right) \sqrt{\frac{4(\gamma-1) M g}{\sqrt{2} \mu_{0}}}
\end{array}\right) \cdots(11)
\end{gathered}
$$

ただし， $M$ : ロータの質量， $g$ : 重力加速度，上部電 磁石で $\gamma M g$, 下部電磁石で $(\gamma-1) M g$ の力で吸引する とする.

また，安全余裕を見てここでは仮にこのバイアス電 流 $I_{\mathrm{hasi}}$ を運転速度 $\omega[\mathrm{rad} / \mathrm{sec}]$ の 2 倍の周波数まで確 保しようとすると，

$$
\begin{aligned}
& I_{\text {bias } 1}=\frac{V}{\sqrt{R^{2}+(L \cdot 2 \omega)^{2}}} \\
& \therefore V=\sqrt{R^{2}+(L \cdot 2 \omega)^{2}} I_{\text {bias } 1}
\end{aligned}
$$

ただし $V$ : コイルの電圧・また消費電力 $P_{1}, P_{2}$ は次 のように表される.

$$
\begin{aligned}
& P_{1}=V I_{\text {bias } 1}=\sqrt{R^{2}+(L \cdot 2 \omega)^{2}} I_{\text {bias } 1}^{2} \\
& P_{2}=V I_{\text {bias } 2}=\sqrt{R^{2}+(L \cdot 2 \omega)^{2}} I_{\text {bias } 2}^{2}
\end{aligned}
$$

ここで，コイルの抵抗を定式化するために次の仮定を おく.コイルは鉄心まわりに何重にも巻かれるが，コ イル一回巻きあたりの長さは常に鉄心の周長さに等し いとする. また，鉄心の断面は多くの場合，図 2 のよ うに長方形断面であり各辺の長さの比を $W_{\text {sed }}$ : $W_{\text {beaning }}$ $=1: \boldsymbol{\alpha}$ とし, この $\boldsymbol{\alpha}$ を鉄心断面形状係数と呼ぶ(こ こでは，鉄心の円周方向長さを $\ell$ と，軸方向長さを $\boldsymbol{\alpha}$ とする）. この仮定のもとにコイルの抵抗 $\boldsymbol{R}$ とイ ンダクタンス $L$ を求めると

$$
R=\rho \frac{l_{\text {coil }}}{S_{\text {coil }}}=k_{R} \sqrt{N^{2} S}, k_{R}=\frac{8 \rho}{\pi D_{\text {coil }}^{2}} \sqrt{\frac{(1+\alpha)^{2}}{\alpha}}
$$

$$
L=\frac{\mu_{0} N^{2} S}{\frac{l}{\mu_{s}}+2 X}=k_{L} N^{2} S, k_{L}=\frac{\mu_{0}}{\frac{l}{\mu_{s}}+2 X}
$$

ただし，looil はコイル長さ，Sooil はコイル断面積，Dooil はコイル直径，øは抵抗率を示す.

インダクタンスはエネルギが保存されることを考 えると, 消費電力は次式で表される.

$$
\begin{aligned}
& P_{1}=V I_{\text {bias } 1}=R I_{\text {bias } 1}^{2}=k_{\text {bias } 1}^{2} \sqrt[2]{\frac{k_{R}^{2}}{N^{2} S}} \\
& P_{2}=V I_{\text {bias } 2}=R I_{\text {bias } 2}^{2}=k_{\text {bias } 2}^{2} \sqrt{\frac{k_{R}^{2}}{N^{2} S}}
\end{aligned}
$$

よって，上下に電磁石を有する場合でも，バイアス電 流による消費電力を小さくするためには，NS くすれば良いことが分かる.

次に動的な吸引力について考えると, 式(10)より

$$
\begin{aligned}
& F_{\text {dynamic }}=2 k \frac{I_{\text {bias } 1}-I_{\text {bias } 2}}{\left(X+X_{0}\right)^{2}} i^{\prime}-2 k \frac{I_{\text {bias } 1}{ }^{2}-I_{\text {bias } 2}{ }^{2}}{\left(X+X_{0}\right)^{3}} x^{\prime} \\
& =k_{i}{ }^{\prime} i^{\prime}-k_{x}{ }^{\prime} x^{\prime} \\
& k_{i}{ }^{\prime}=2 k \frac{I_{\text {bias } 1}-I_{\text {bias } 2}}{\left(X+X_{0}\right)^{2}}, k_{x}{ }^{\prime}=2 k \frac{I_{\text {bias } 1}{ }^{2}-I_{\text {bias } 2}}{\left(X+X_{0}\right)^{3}} \cdots
\end{aligned}
$$

と表せる. ここで，第一項の係数 $k_{i}^{\prime}$ を大きくし，第 二項の倸数 $k_{x}$ 'を小さくすると同じ大きさの力を発生 させるために必要な制御電流は少なくなることがわか る. 第一項, 第二項の係数は, 次のようになる.

$$
\begin{aligned}
& k_{i}^{\prime}=\frac{\sqrt{4 M g \mu_{0}}}{\left(X+X_{0}\right)}(\sqrt{\gamma}-\sqrt{\gamma-1}) \sqrt{N^{2} S} \\
& k_{x}^{\prime}=\frac{2 M g}{\left(X+X_{0}\right)}=\text { const. }
\end{aligned}
$$

よって，NSE大きくすれば良いことがわかる.

電磁石を設計する上でコイルの巻き数の 2 乗と鉄 心断面積の積 $N S S$ を大きくするように設計すると電 力効率の良い電磁石を設計することができることが分 かる. これは電磁石の評価・比較にも用いることがで きる. また， 吸引力の制御電流に対する線形性を保つためには $\boldsymbol{\gamma を}$ 大きくする必要があるので, ここでは $\gamma=2$ と仮定し ている.

実際の設計においては，(1)磁束飽和，(2)軸受幅径 比, (3)アンプ容量による出力電王・出力電流に制限, (4)軸受の大きさなどを考慮する必要がある. 
ここではまず，(1)磁束飽和について考える．磁束密度 を $B[T]$ とすると吸引力は, 次式で表される.

$$
\begin{aligned}
& F=\frac{B^{2}}{2 \mu_{0}} 2 S=\gamma \frac{M g}{\sqrt{2}} \\
& \therefore B^{2}=\frac{\mu_{0} \gamma M g}{\sqrt{2} S}
\end{aligned}
$$

ここで, 磁気吸引力が電流に対して, 線形性を保てる 範囲を $B_{\text {min }}<B<B_{\text {max }}$ とすると，

$$
\frac{\mu_{0} \gamma M g}{B_{\max }^{2} \sqrt{2}}<S<\frac{\mu_{0} \gamma M g}{B_{\min }^{2} \sqrt{2}}
$$

また，鉄心断面積を決定する際には(2)軸受幅径比 $\boldsymbol{l} \boldsymbol{d}$ を考慮する必要がある. 軸受幅 $\boldsymbol{l}$ を鉄心断面形状係 数 $\boldsymbol{\alpha}$ を用いて $l=\sqrt{\alpha S}$ とし, $0.5<\boldsymbol{l} / \boldsymbol{d}<1.0$ の範井内で設 計すると,

$$
\frac{(0.5 d)^{2}}{\alpha}<S<\frac{(1.0 d)^{2}}{\alpha} .
$$

式(21)(22)より鉄心断面積に対する制約条件が決まる.

次に(3)アンプの容量による制限について考える.

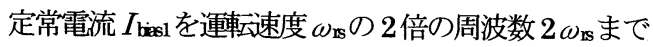
出力するために必要となる電圧 $V$ を求めると,

$$
V=k_{\text {bias } 1} \sqrt{k_{R}^{2}+4 k_{L}^{2} \omega_{r s}^{2} N^{2} S}
$$

ここで, アンプの出力電圧範囲を $V_{\text {min }} \sim V_{\text {max }}$, 最大連 続出力電流を $I_{\max }$ とすると,

$$
I_{\text {biasl }}=\frac{k_{\text {biasl } 1}}{\sqrt{N^{2} S}}<I_{\max } \therefore \frac{k_{\text {bias } 1}{ }^{2}}{I_{\text {max }}{ }^{2}}<N^{2} S \cdots(24)
$$

式(24)より $N S$ S範用が求まる. このとき, 前に述べ たように $N P$ を大きくするにつれ消費電力は小さく なるが，鉄心断面積 $S$ コイル巻き数 $N$ を大きくす

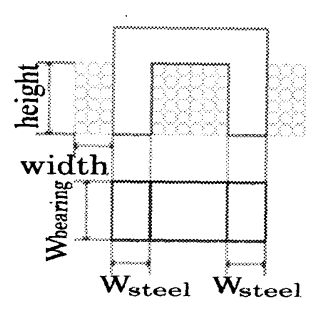

Fig.2 Configuration of electromagnet

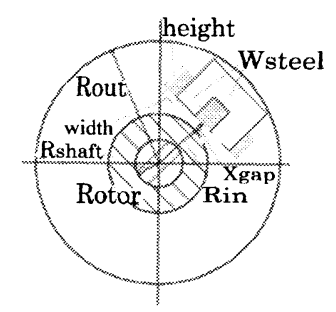

Fig.3 Cross section of electromagnet
ると軸受の大きさが大きくなることは容易に想像でき る. そこで，(4)軸受の大きさを考虑した上て鉄心断面 積 $S$ コイル巻き数 $N$ を設計する必要がある. ここで は，設計者が軸受の外径に上限を与えた時に，その軸 受外径に納まる軸受で，かつ消費電力の小さい軸受， つまり NPS が大きい軸受を設計する. その具体的設 計法を以下に示す. 図 3 のような軸受を考えて, 軸 受・電磁石の寸法を設計変数により定式化する. 軸受 内径 $R_{\mathrm{n}}$ と鉄心幅 $W_{\text {stod }}(=\sqrt{S / \alpha})$ より, コイルを巻く 空間の幅 width と高さ heightを定式化する.

ここで電磁石の幅 $W_{\text {met }}$ は次のように表される.

$$
W_{\text {magnet }}=2 \cdot\left(W_{\text {steel }}+2 \cdot \text { width }\right)
$$

この電磁石の幅 $W_{\text {mente }}$ が仮にロータ外周の $1 / 4$ に納ま り, その中にコイルの巻き数 $\boldsymbol{N}$ が確保でき, 軸受外 径 $R_{\text {at }}$ が一定值 $R_{\text {max }}$ 以下で設計する，という条件を加 えると，

$$
N^{2} S \leq \frac{\left(\sqrt{S / \boldsymbol{\alpha}}-R_{\max }+R_{i n}\right)^{2}\left(\sqrt{S / \boldsymbol{\alpha}}-R_{i n}\right)^{2} S}{D_{\text {wire }}{ }^{6}}
$$

ただし，上式の右辺つまり $N S S$ 上限は鉄心断面積 $S$ に関する関数であり，鉄心断面積 $S$ は式(21)(22)に示 された範井内から $0<\sqrt{S}<R$ 只範囲内で変動する.

よって $N S S$ の限を最大にするように鉄心断面積 $S$ を決定する.

また, 式(24)(26)で NPSについての条件が示された. これらの条件を満たす範用内で $N P S$ が最大になるよ うにコイル巻き数 $N$ を設計する.

これにより, 設計者が軸受外径の上限を与えると ロータ質量・ロータ直径・定常ギャップより磁束飽和 やアンプ容量などを考虑して鉄心断面積とコイル巻き 数を決定することができる.

\section{3. 同時最適設計の流れ}

一般にこの様な系の最適設計問題は多峰性である ことから, 本設計システムでは, 設計者が入力した設 計仕様に対して従来の設計方法と同様にロータ・磁気 軸受系の別々設計を行い，これを初期設計とし，この 設計結果を最適設計の初期值としてロータ・磁気軸受 系を同時最適設計する.

3.1 初期設計初期設計過程では, 従来の回転 機械の最適設計力法と同様に構造系と制御系を独立に それぞれ最適設計を行う. すなわち，ロータ，電磁石， 制御系を別々に最適設計する. したがってこの最適設 
計を別々最適設計と呼ぶが，得られた最適值を同時最 適設計の初期値として用いるので, 初期設計と呼ぶこ ともある. 初期設計のフローチャートを図 4 に示す.

3.2 同時最適設計本節では, ロータ・磁気軸 受・制御系についての設計変数を制約条件のもとで評 価関数を小さくするような同時最適化について述べる. 評価関数には磁気軸受におけるコイル電流の消費電力 と軸受体積を用いている. また最適化にはペナルティ 法を用い，図5にそのフローチャートを示す。

次に評価関数の定式化について述べる．まず，コ イルの消費電力 $P$ を上下部の電磁石におけるバイア ス電流 - 動的制御電流の消費電力の総和と定義すると, 式(16)(17)より，

$$
P=R\left(I_{\text {bias } 1}^{2}+I_{\text {bias } 2}^{2}\right)
$$

\section{と表せる.}

次に，軸受体積は前述したように軸受幅を $l=\sqrt{\alpha S}$ とすると，軸受外径 $R_{\text {aut }}$ 用いて，

$$
V_{\text {bearing }}=l \times \pi R_{\text {out }}^{2}
$$

\section{と表わされる.}

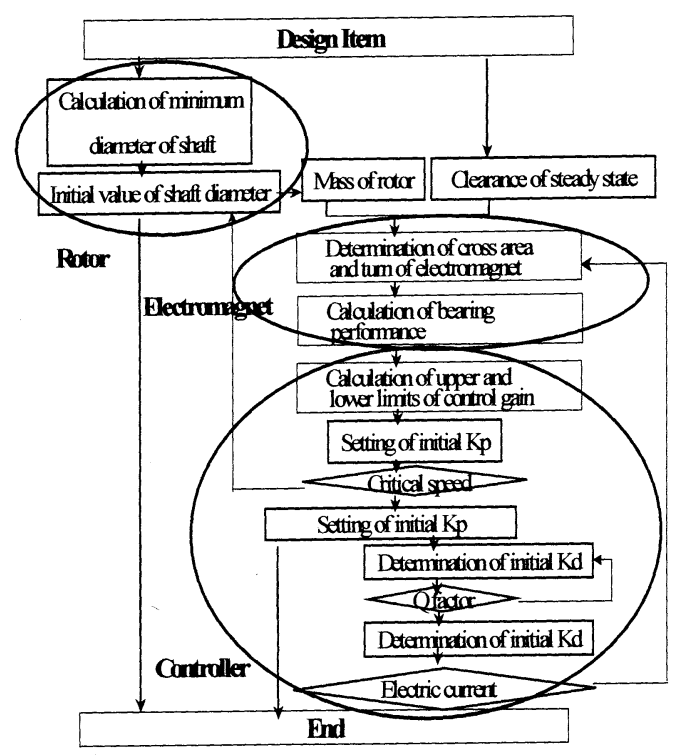

Fig.4 Flowchart to decide the initial value (Individual optimum design)
これらを用いて評価関数を次式のように定式化する.

$$
J=\frac{P}{P_{0}}+\alpha_{\omega} \frac{V_{\text {bearing }}}{V_{\text {bearing } 0}}
$$

ただし， $\alpha_{\omega}$ は重み関数，添字 0 は初期設計に対 する評価值を示す.

\section{4. 設計結果と振動解析およひ考察}

ここでは，実際に本システムを用いて設計を行っ た際の別々最適設計結果と同時最適設計結果の例を示 し, post design analysis を行い,これにより, 雨最適 設計ともに実現可能な設計であること確認する.振動 解析はロータ・磁気軸受系の危険速度線図, モード形 状, 共振曲線, Q 值, 時刻歷応答, 制御電流などにつ いて行っている.

4.1 設計仕様と設計結果および考察設計の一 例として実用化されている $1250[\mathrm{~kW}]$ 遠心圧縮機 （13000[rpm])を参考に設計を試みる. 表 1 に示寸設計

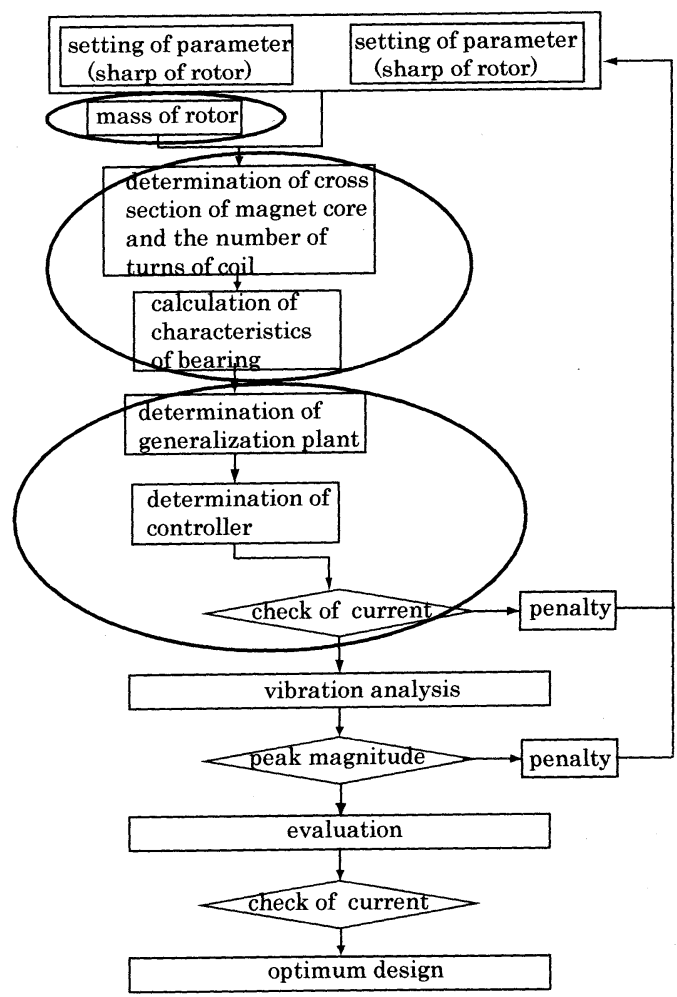

Fig 5 Flowchart of simultaneous optimum design 
仕様の下に最適設計を行う。この設計仕様を本設計シ ステムに入力した場合の別々最適設計と同時最適設計 の結果を表 2 に示寸. 各設計变数の制約条件（最小 值・最大值) と各諸元も同表に掲載している. 雨最適 設計後の軸形状に関しては図6に図示寸る.

表 2 およひ図 6 で示した別々最適設計結果と同時 最適設計結果について比較・検討する. ロー夕は対称 とし軸直系は端から各段ごとに $d_{1} \sim d_{4}$ としている.

ロータについて考察すると, 同時最適設計のロー 夕質量は, 別々設計のロータ質量に比べて $15.3 \%$, 軸 受間隔とオーバーハング長に関しては, 最適値がほぼ 最小值と等しい值に収束した。これは, ロータの長さ をできる限り短くすることが，ロー夕質量が小さくな ることや振動学的に有利であることに裏付けられる. 次に電磁石・軸受の設計について考察すると, 以前は 電磁石単体を評価することは難しかったが， 22 節で 提案したコイル巻き数の 2 乗と鉄心断面積の積 $N^{2} S$ を評価に用いると電磁石単体の評価ができる. ここで, 同時最適設計では別々最適設計に比べ $N^{2} S$ が $13.7 \%$ 向上されている.これは評価関数に含まれる軸受体 積・消費電力の低減につながる. 実際に同時最適設計 の軸受体積は別々最適設計に比べ $16.8 \%$ 小さくするこ とができた. 軸受外径は別々最適設計に比べて大きく なっているが，設計者が設定する軸受外径の制限（最 大値)よりも小さく収まっている，また，軸受幅が初 期設計に比べ小さくなっているため, ロー夕長は $2.76 \%$ 短くできている.これはまた，ロー夕質量・消 費電力の低减にも貢献している.

最後に，制御ゲインの設計について考察すると， 大きさについては, 同時最適設計と別々最適設計の場 合で電磁石が異なるので一概には比較できない，ただ し，その結果としてバイアス電流の大きさは $127 \%$,

Tablel. Design specifications

\begin{tabular}{|c|c|c|}
\hline Operating condition & Operation speed & $13000[\mathrm{~mm}]$ \\
\hline & Shaft power & $1250[\mathrm{kw}]$ \\
\hline Rotor & Number of disk & 6 \\
\hline & Diameter of a disk & $280[\mathrm{~mm}]$ \\
\hline & Width of a disk & $20[\mathrm{~mm}]$ \\
\hline & Interval of a disk & $110[\mathrm{~mm}]$ \\
\hline & Interval of a disk and bearing & $300[\mathrm{~mm}]$ \\
\hline & Overhang length & $150[\mathrm{~mm}]$ \\
\hline Capacity of amplifier & Continuable output current & $30[\mathrm{~A}]$ \\
\hline & Peak current & $60[\mathrm{~A}]$ \\
\hline & Maximum output voltage & $400[\mathrm{~V}]$ \\
\hline
\end{tabular}

消費電力は $15 \%$ 低减できた. また，同時最適設計に より軸受剛性は大きくなっているが，このとき制御電 流は磁束飽和電流・アンプの飽和電流よりも小さく, この軸受剛性は実現可能である.

別々最適設計よりも同時最適設計の方が評価関数 に取り入れた消費電力・軸受体積ともに小さくできる ことがわかった. しかし，このことよりも別々最適設 計と同時最適設計がともに実現可能であり，かつ安全 な設計であることが重要である. よって, 設計結果に 対して設計後解析の結果を次節に示し, 両最適設計と もに実現可能かつ安全であることを確認する.

Table2. Design result

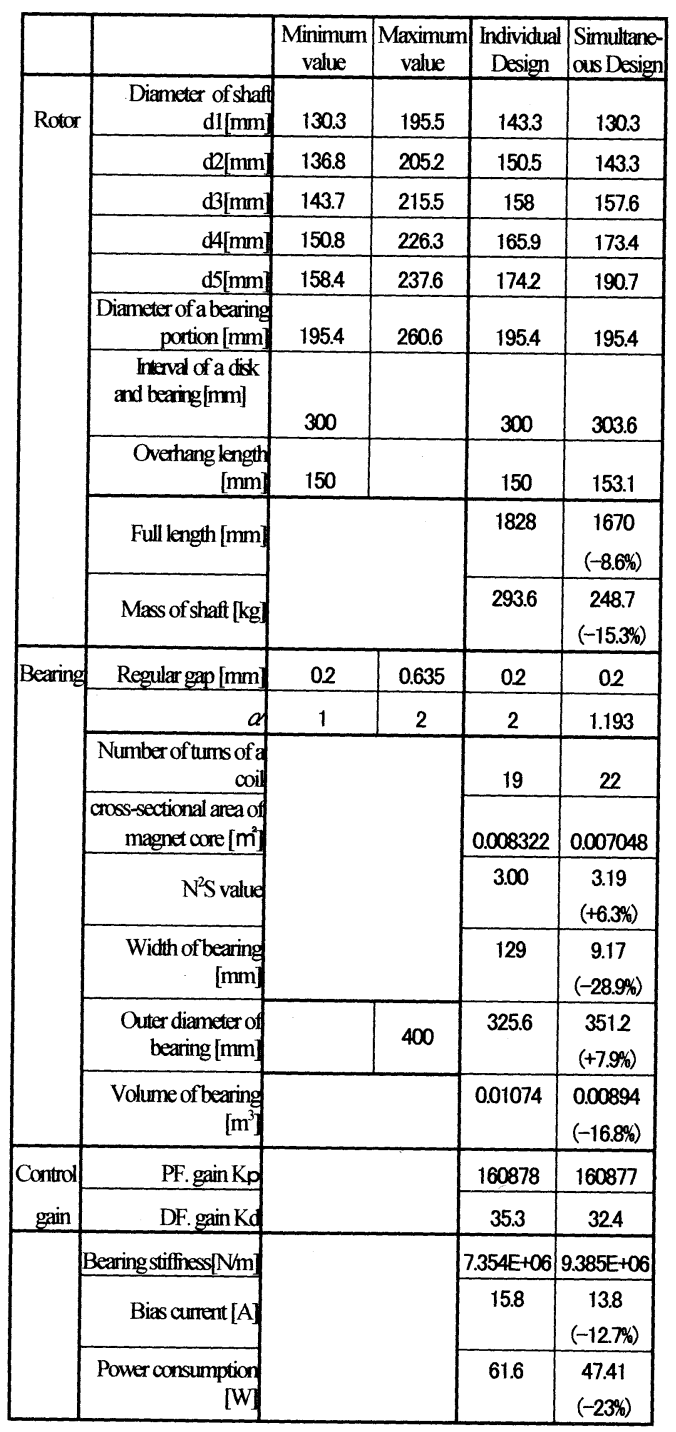




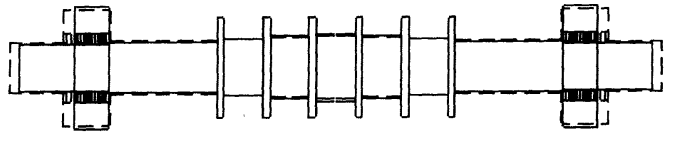

Fig.6 Configuration of rotor for before and after optimum design

\section{2 振動解析および考察 PostDesign Analysis .}

として以下の解析を行った.

(1) 危険速度線図（固有振動数）・モード形状, 回転 速度と固有值の関係を表す危険速度線図より, ロー夕 の特性・運転速度と危険速度の関係を確認寸る.また 実際に，系全体の固有值解析により求めた危険速度が 運転速度から十分に離れているか確認する。

(2) 共振曲線（Q值)

図 7 亿両最適設計の結果に対する共振曲線を示す。 また，Q值を表3に示している. また, 別々最適設計 (1)と別々最適設計(2)で表された共振曲線は別々最適設 計の途中過程での共振曲線を示している. ここで, こ の共振曲線を用いて本設計システムの流れについて説 明する。

まず，図 7 の最低次の共振は剛体モードであり， 回転速度が低いから，速く通過寸れば振動が大きくな らないのでこの部分の検討は省略し，曲げ 1 次振動に ついて検討する. 別々最適設計(1)入力された設計仕 様より求めた設計変数の初期值に対する共振曲線であ る. 別々最適設計(2)は(1)で色険速度が運転速度付近に あるため, ロータの軸侱を大きくする必要があり, 運 転速度が危険速度の土20\%以上離れるまでロー夕軸佳 を大きくし, 大きくした共振曲線である. 別々最適設 計(3)別々最適設計(2)の共振曲線では $Q$ 值が 10 以上

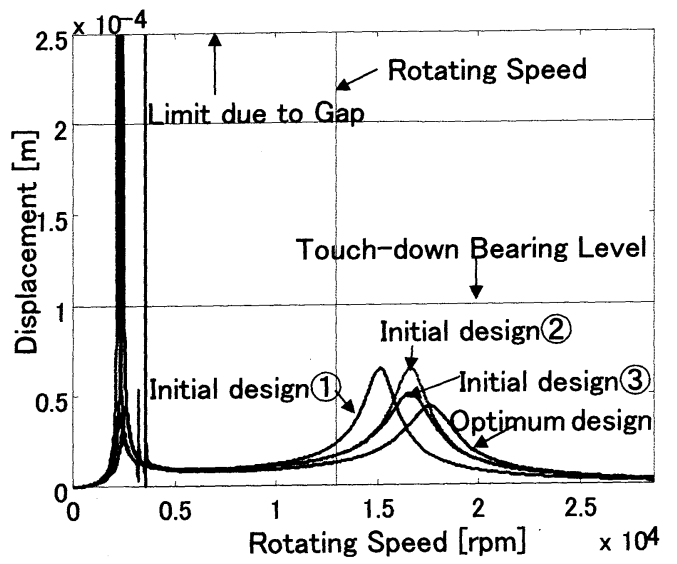

Fig7 Resonance arve
で, 速度フィードバックゲイン $K_{\mathrm{d}}$ を大きくする必要 があり，減衰を十分に確保できるまで，つまりQ值が 10 以下になるまで速度フィードバックゲインを大き くした共振曲線である.このように構造系と制御系を 別々に最適設計した設計結果を同時最適設計の初期值 として最適化を行い，その解を同時最適設計結果とし 共振曲線を示している.

ここでは，別々最適設計と同時最適設計に対する 共振曲線について以下の事項を確認する．まずは，運 転速度が色険速度から十分に離れていること．また， 定格速度まで回転数を上昇させる際に通過する危険速 度において振動振幅がロータ・タッチダウンベアリン グ間のギャップ以下であること．かつ，危険速度にお けるQ値が 10 以下であることを確認する.

図 7,表 3 から解かるように, 実際に別々最適設 計・同時最適設計ともにこれらの条件を満たしている. (3) 時刻歴応答

次に，害際に運転する際のシミュレーションを行 う。具体的には起動時から定格速度まで回転数を上げ， 定格速度で定常運転する時までの時刻歷応答について 調べる.ここでは，ロータがタッチダウンベアリング に接触しないことを確認することができた。

すなわち起動時の軸を持ち上げる時の時刻歷応答 と定格速度まで回転数を上げ，その定格速度で定常運 転する時の時刻歴応答について調べる. 図 8,9 に最 適設計された場合の起動時と加速時・定常運転時の時 刻歷応答を示寸。ここでは，ロータがタッチダウンベ アリングに接触しないことを確認する.

起動時の時刻歷応答を調べると, 目標値（浮上位 置）を中心とし，片振幅が定常ギャップの $1 / 2$ 以内に 抑えられタッチダウンベアリングに接触しないことが 分かる. また，浮上位置は目標值に十分近く定常偏差 も小さいことがわかる.

次に，加速時・定常運車時の時刻歷応答について考 える. これも初期設計・最適設計ともに片振幅が定常 ギャップの $1 / 2$ 以下であり, タッチダウンベアリング に接触しないことが分かる.

Table3. QFactor

\begin{tabular}{|l|c|c|}
\hline & Initial design & Optimum design \\
\hline 1st critical speed [rpm] & 2239 & 2575 \\
\hline 2nd critical speed [rpm] & 3217 & 3921 \\
\hline 3rd critical speed [rpm] & 16652 & 17665 \\
\hline 4th critical speed [rpm] & 40775 & 39643 \\
\hline \hline Rated operating speed[rpm] & 13000 & 13000 \\
\hline
\end{tabular}




\section{(4) 制御電流}

電磁石ではコイルに流れる電流を制御することによ り磁気吸引力を制御寸る. しかし，前にも述へたよう に, アンプの容量により出力できる制御電流に限界が ある. 特に，高周波においてはインダクタンスの影響 が大きくなり, アンプの性能として定められている連 続出力電流を確保できなくなってしまう. また, たと え電流を出力できたとしても磁束飽和を起こしてしま うと磁気吸引力を発生させることができなくなってし まう.よって, 実際の運転時に必要な制御電流を出力 可能であるか確認する必要がある. また, 制御電流が 磁束飽和電流以下である必要がある，運転時に必要な 制御電流とは，定常運転時および起動時や危険速度通 過時に必要な大きな制御電流である. よって, この起 動時と危険速度通過時の制御電流に関しても拘束条件 を満たしているかどうか確認することができた.

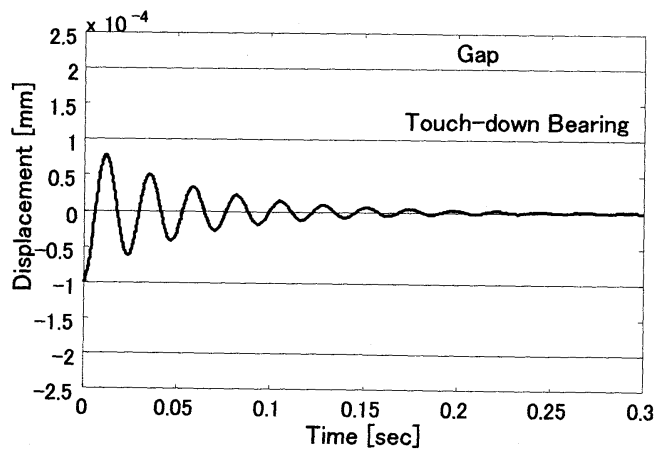

Fig8 Timehistory at the start

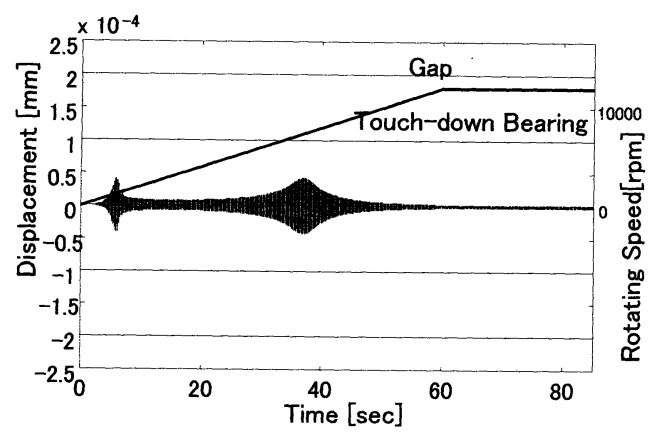

Fig,9 Timehistory of start up and steady operation

\section{5. 結言}

本研究では同時最適設計を用いたロータ・磁気軸 受系の設計システムを構築した. このことより, 以下 の知見を得た。

(1)電磁石の設計において，コイル巻き数 $N$ の 2 乗と 鉄心断面積 $S$ の積 $N^{2} S$ を電磁石の性能評価として用 いると様々な電磁石の比較・評価を行うことができる. (2) $N^{2} S$ の評価を用いると磁気軸受用の電磁石を設計 する際に，軸受外径の上限と鉄心断面形状を与えるこ とにより運転条件・ロー夕質量・鉄心断面形状に応じ て磁束飽和やアンプ容量などを考慮し, 電磁石を設計 することができる. すなわち設計者が軸受外径の上限 を入力すると軸受内径と鉄心断面形状係数を設計変数 とし， $N^{2} S$ を評価関数とする最適化問題を解くこと により電磁石の最適設計を行うことができる.

(3)ロータ・磁気軸受・制御系の同時最適設計を行い, 別々最適設計より設計変数およびロータの振動, 制御 電流等で優れた結果を得ることができた. また設計 後解析を行うことによりこの設計結果が設計仕様を満 たすものであることが確認できた.

\section{文献}

(1) Iwatasubo. T., et al, Research Trends and Future Subjects on Simultaneous Optimum Design of Structural and Control Systems for Mechanical Structure, Transactions of the Japan Saciety of Mechanical Engineers, Series C, Vol59, No.559 (1993-3), pp.631-637

(2) Iwatasubo. T., et al, Development of Simultaneous Optimum Design of Structural and Control System of Flexible Structures, Transactions of the Japan Society of Mechanical Engineers, Series C, Vol.57, No.534 (1991-2) , pp.407-412

(3) Yamakawa, H., Simultaneous optimization problem of structural and control systems, Text of JSME Seminar, Vol.920, No.50(1992), pp.39-54

(4) Oginata, G., Simultaneous optimum design problem of structural and control systems, Instrument and control, Vol36, No.4 (1997) , pp.254-261

(5) Matsushita, O., Standardization of Evaluation Stability Margin for Active Magnetic Bearing Equipped Rotors, Proc. of ImechE, No. C576-101 (2000-), on CD-ROM 